\title{
artículos
}

\section{Iconografía de América en el cine: A propósito de El Dorado (1988), de Carlos Saura}

\author{
Angélica García Manso \\ Universidad de Extremadura
}

PALABRAS CLAVE: Iconografía/ Cine

\section{RESUMEN}

El Dorado (1988), filme del director español Carlos Saura, constituye un excelente ejemplo de cómo la iconografía de América puede ser estudiada desde el Cine. El presente artículo propone una clasificación y análisis de los mitos y tópicos relativos a la imagen del Nuevo Mundo que es posible detectar en esta película de Saura así como una lectura de la misma a partir de la confluencia de mitos clásicos y contemporáneos que de ella se desprenden.

ABSTRACT

El Dorado (1988), by the Spanish filmmaker Carlos Saura, is an excellent example of how the iconography of America can be studied from the Cinema. This article proposes a classification and analysis of the myths and topics concerning the image of the New World which is possible to detect in this film by Saura, and an interpretation of the film starting from the confluence between classical and contemporary myths which are present in it.

El descubrimiento de América materializó un sueño presente durante siglos en el imaginario colectivo del Viejo Continente: hallar un nuevo espacio que supusiera la "alteridad", la "contraimagen", el reverso de la realidad europea. Así, el bautizado como Nuevo Mundo habría de convertirse en ese lugar desconocido del planeta en el que iban a converger todas aquellas virtudes que el hombre occidental creía perdidas y pretendía reencontrar.

En efecto, conquistadores y cronistas coincidieron en describir y analizar la realidad americana de forma apriorística, a través de las categorías de lo ya existente. Ello explica que su interés por adquirir datos novedosos y objetivos sobre las nuevas tierras no fuera excesivo, centrando sus esfuerzos más bien en verificar una serie de anhelos, así como símbolos y arquetipos, que precedían al propio descubrimiento. Es ésta una circunstancia que va a permitir, por ejemplo, que antiguos mitos y

* GARCÍA MANSO, Angélica: “Iconografía de América en el Cine: A propósito de El Dorado (1988), de Carlo Saura", Boletín de Arte $n^{\circ} 28$, Departamento de Historia del Arte, Universidad de Málaga, 2007, págs. 425450. 
leyendas occidentales sobre "otros mundos posibles" se actualicen y puedan ser reinterpretados en latitudes americanas.

Dichos símbolos y mitos sobrevivieron en el llamado "cuarto continente" a través de una repetición sucesiva y permanente que, aparte de los textos, afectó también a la iconografía 1 , la cual quedó sometida al estereotipo y dio lugar a una serie de constantes figurativas. $Y$ es que, desde su descubrimiento, América se convierte en una fuente inagotable de imágenes en las que se combinan el mito ${ }^{2}$, el tópico ${ }^{3}$ y la utopía 4 .

Reflejada tradicionalmente a través del grabado, la pintura, la escultura y las artes decorativas, la imagen de América encuentra en la Edad Contemporánea nuevos soportes como la fotografía, la publicidad, el cómic, los medios informáticos y el cine. El desarrollo y solidez que este último ha alcanzado a lo largo de la última centuria (de hecho, el Cine ha sido definido como "el arte del siglo XX") lo convierte en un medio idóneo para la recreación y gestación de iconografía relacionada con el continente americano.

En este sentido, el objetivo que se proponen las presentes páginas consiste en analizar e interpretar la imagen de América que Carlos Saura recrea en su película El Dorado (1988), tema que en dicho filme puede detectarse, como mínimo, a través de tres vías:

- La presencia explícita e implícita de diversos mitos.

- Los tópicos utilizados para contextualizar la acción fílmica.

- La simbiosis que se produce entre iconos y mitos generados en Europa durante las Edades Moderna y Contemporánea, y el espacio americano.

Todo ello con el propósito último de dejar constancia de cómo América, casi

1 En términos muy generales, por "iconografía" se entiende la rama de la Historia del Arte que estudia el origen, formación y desarrollo de los temas figurados así como los atributos con que se identifican y de los que normalmente van acompañados. Cualquier acercamiento a este tema hace indispensable la consulta de los estudios de E. PANOFSKY, que se han convertido en todo un clásico en esta materia.

2 El "mito", definido a grandes rasgos como un relato que, bajo forma de alegoría, traduce una generalidad histórica, social, física o filosófica, es una realidad cultural compleja que puede abordarse e interpretarse desde perspectivas múltiples y complementarias. Las aproximaciones a la cuestión han llenado páginas y más páginas, sin alumbrar, empero, una definición consensuada. Así puede constatarse, por ejemplo, en mas paginas, sin alumbrar, empero, una definicion consensuada. Asi puede constatarse, por ejemplo, en GRAF, F.:
págs. $1-8$.

3 El concepto de "tópico", que procede de la retórica grecolatina, permaneció durante siglos íntimamente ligado a la tradición literaria. Sin embargo, su definición como "lugar común" o "motivo reiterado" es válida tanto aplicada al texto como a la imagen.

4 Aunque los orígenes del concepto de "utopía" se remontan a las reflexiones políticas de Platón y las lecturas que de ellas hacen autores tan significativos como Cicerón en el ámbito romano y San Agustín en el panorama latinocristiano, la percepción actual -como es de todos sabido- procede de Tomás Moro y su obra Utopía, en la que imagina un mundo ideal de las relaciones humanas al tiempo que ironiza sobre él. Trasladada al contexto del descubrimiento y conquista de América, la utopía hace referencia a esa noción de "paraíso" que los europeos deseaban encontrar en las nuevas tierras. 
cuatrocientos años después de su descubrimiento, sigue apareciendo como un territorio virgen sobre el que el artista actual puede proyectar un nuevo corpus iconográfico y mítico surgido en el Viejo Continente durante los últimos siglos.

2.- EL DORADO. CONTEXTUALIZACIÓN HISTÓRICA Y CINEMATOGRÁFICA DEL FILME.

\section{1.- Cine e Historia. UnA bReVe aproximación.}

Desde los relatos homéricos y los monumentos conmemorativos de la Antigüedad Clásica hasta la fotografía periodística, pasando por la pintura histórica y la estatuaria pública, la Historia ha abastecido temáticamente a las diferentes artes plásticas, literarias y musicales, tendencia ésta que se intensificaría a partir del Neoclasicismo y el Romanticismo.

Cuando a finales del siglo XIX surja el arte cinematográfico también se recurrirá a la Historia en busca de referentes temáticos: así, en el temprano año de 1898 Méliès dedica uno de sus tableaux vivant a la Roma de Nerón (Neron essayant des poisons sur des esclaves) y en esos mismos años se registran ya las primeras aproximaciones a personajes como Jesucristo, Cleopatra y Juana de Arco, entre otros. Desde entonces, el conocido como film d'art francés, el colosalismo del primitivo cine italiano, las aportaciones de D. W. Griffith, el cine histórico alemán mudo y un largo etcétera que se prolonga hasta la actualidad más inmediata (sirvan como ejemplo Alejandro Magno -Alexander-, de Oliver Stone, y El reino de los cielos -Kingdom of Heaven-, de Ridley Scott, ambas de 2005) han contribuido a forjar un estrecho vínculo entre Cine e Historia. $Y$ es que, efectivamente, ambas disciplinas comparten su condición de discursos actualizadores del pasado.

No es nuestro propósito enumerar aquí la amplia lista de analogías o afinidades que es posible establecer entre el Cine y la Historia. Nos limitaremos, por tanto, a esbozar sucintamente la génesis de la relación entre el arte fílmico y la disciplina histórica. Grosso modo, la Historia tiene por objetivo reconstruir lo acontecido en un tiempo más o menos lejano, un pasado que siempre es evocado desde el presente. De otro lado, una de las tendencias del arte cinematográfico desde sus comienzos fue la de situar la acción de los filmes en un tiempo pretérito que es reconstruido y representado a través de los mecanismos discursivos del Séptimo Arte, algo que dio lugar al denominado "género histórico".

Así pues, incapaz de ofrecer un contacto directo e inmediato con la realidad, el Cine pone sus dispositivos característicos al servicio de la representación de la Historia, la cual, por su parte, remite también a una realidad distante 5 .

El Dorado, que recrea uno de los episodios más conocidos del descubrimien- 
to y la conquista de América, se inscribe pues dentro de dicho género histórico, concretamente en lo que podría denominarse "ficción histórica documentalizada", puesto que recurre a fuentes documentales para adquirir connotaciones de verosimilitud y rigor6.

\section{2.- El contexto del V Centenario del Descubrimiento de América.}

España aprovecha la coyuntura del año 1992 para ubicarse en el contexto internacional una vez consumado su ingreso en la Unión Europea. Se diseñan, pues, tres ingentes proyectos en torno a esta efemérides: los Juegos Olímpicos de Barcelona, la Exposición Universal de Sevilla y la Sociedad Estatal del V Centenario. La acción de esta última queda reflejada a través de una abundante producción editorial, la organización de exposiciones y congresos y, particularmente, la financiación de coproducciones televisivas y cinematográficas en torno al tema del Descubrimiento de América. En este sentido, cabe citar filmes como Cabeza de Vaca (1991), de Nicolás Echevarría, o las dos películas producidas un año más tarde en torno a la figura de Cristóbal Colón (Cristóbal Colón: el descubrimiento -Christopher Columbus: the discovery-, de John Glen, y La conquista del paraíso -Conquest of paradise-, de Ridley Scott).

Aunque la idea de Carlos Saura de hacer una película sobre El Dorado se remontaba, como mínimo, a 1982, los problemas de producción que se le plantearon hicieron que el estreno del filme no tuviera lugar hasta 1988. Así pues, El Dorado vino a sumarse a este conjunto de películas de tema americano que proliferaron entre finales de los años ochenta y principios de los noventa (prueba de ello es que en los créditos finales del largometraje aparece el logotipo de la Sociedad Estatal del V Centenario, coproductora del mismo).

\section{3.- El Dorado en la filmografía de Carlos Saura.}

Entre finales de los años sesenta y principios de la nueva década, coincidiendo con la expansión internacional de la nouvelle vague francesa, surge una nueva generación de cineastas que se propone renovar el cine español.

5 Vid. MONTERDE, J. E., M. SELVA MASOLIVER Y A. SOLÀ ARGUIMBAU: La representación cinematográfica de la Historia. Madrid, Akal, 2001, passim. Una aproximación al género histórico desde presupuestos didácticos es el que propone José Uroz. Vid. UROZ, J. (Ed.): Historia y Cine. Publicaciones de la Universidad de Alicante, 1999 .

${ }^{6}$ Carlos Saura señala que para la confección del guión de esta película manejó las crónicas de Toribio de Ortiguera, Francisco Vázquez y Pedrarias de Almesto, así como las Elegías de varones ilustres, de Juan de Castellanos. Cf. SAURA, C.: EI Dorado: guión, fotogramas, documentos e historia de mi película. Barcelona, Círculo de Lectores, 1987, pág. 178. 
Entre ellos figura Carlos Saura (Huesca, 1932), quien, con el objetivo -entre otros muchos- de adaptar la tradición buñueliana a la realidad española coetánea, da lugar a un tipo de cine alegórico y simbólico, cargado de "segundas intenciones", con el que saca a la luz los fantasmas colectivos de la sociedad española.

A grandes rasgos, dentro de su amplia filmografía es posible establecer cierta correspondencia cronológica y temática en dos grupos bien diferenciados:

En primer lugar, el que se inaugura con La caza (1965) y sigue con películas como Peppermint frappé (1967), El jardín de las delicias (1970), Ana y los lobos (1972), La prima Angélica (1973), Cría cuervos (1975), Elisa, vida mía (1977) y Mamá cumple cien años (1979), entre otras, todos ellos largometrajes de una gran calidad y con los que obtiene prestigio y aceptación internacionales.

A partir de la década de los ochenta desarrolla su faceta musical y coreográfica en la gran pantalla con títulos como Bodas de sangre (1981), Carmen (1983), El amor brujo (1986), Sevillanas (1992), Flamenco (1995), Tango (1998) y Salomé (2002).

Pero esta clasificación no impide la existencia de títulos singulares o difícilmente encasillables, como es el caso de la adaptación de la obra de teatro de Sanchís Sinisterra ( Ay Carmela! -1990-) o, por citar uno de sus últimos filmes, la versión que de los sucesos ocurridos en la localidad extremeña de Puerto Hurraco lleva a cabo en El séptimo día (2004). Lo mismo sucede con sus aproximaciones al cine de tema histórico, al que ha dedicado, al menos, tres películas: La noche oscura (1989) y Goya en Burdeos (1999), referidos a las figuras de San Juan de la Cruz y Francisco de Goya respectivamente, y El Dorado (1988), película objeto de análisis en las presentes páginas.

\section{4.- SINOPSIS DEL FILME.}

La película narra los principales hechos acaecidos durante la expedición a EI Dorado realizada por las huestes españolas entre 1560 y 1561, jornada dirigida en un primer momento por el navarro Pedro de Ursúa. En el transcurso de esta empresa confluyen una serie de circunstancias (la debilidad de carácter del mencionado Ursúa, reducido a simple marioneta en manos de su amante; la progresiva toma de conciencia por parte de capitanes y soldados de que el suyo puede resultar un esfuerzo inútil; el inhóspito medio en el que se transforma la selva amazónica, etcétera) que dan lugar a una superposición de conjuras para hacerse con el poder. Así pues, a medida que avanza el metraje, el sueño de la conquista y del oro va desvaneciéndose para dejar paso a la destrucción sembrada por dos personajes: Inés de Atienza, la mestiza amante de Ursúa, presentada cual "mujer fatal" que conduce a la muerte a varios capitanes de la expedición, y el sanguinario y cruel Lope de Aguirre, 
promotor de las insurrecciones ya señaladas. Éste, auténtico protagonista del filme, tras exponer sus ideas independentistas y rebelarse contra la monarquía de Felipe II, terminará proclamándose general de la tripulación. El largometraje finaliza in medias res, sin reflejar el desenlace de la jornada. Sólo una voz en off informa al espectador de que Aguirre acabaría siendo asesinado por las tropas del rey?

\section{3.- LA IMAGEN DE AMÉRICA EN EL DORADO.}

En la película que estrena Saura en 1988 pueden detectarse tres tipos diferentes de iconos en lo relativo a la representación del Nuevo Mundo: en primer lugar, los que aluden a ese imaginario mítico colectivo que de Europa se trasladó a América; por otro lado, las imágenes cuya utilización recurrente ha consagrado como tópicos del cuarto continente; finalmente, determinados iconos gestados en el ámbito europeo y que, como sucede en el caso de El Dorado, el arte cinematográfico permite transponer a tierras americanas.

\section{1.- Los MITOS}

La imagen de América transmitida por los europeos que participaron en el descubrimiento y conquista del Nuevo Mundo -y, en especial, por los primeros cronistas- fue el resultado, entre otros muchos factores, de una amalgama de fuentes en la que se entremezclaron mitos de la Antigüedad Clásica, leyendas bíblicas y de civilizaciones asiáticas, creencias medievales, novelas de caballerías, relatos hagiográficos y otras aportaciones de la tradición oral, por una parte, y los mitos precolombinos o indígenas propios de las tierras recién descubiertas, por otra ${ }^{8}$. El filme de Carlos Saura aporta varios ejemplos en este sentido, tal y como se expone a continuación.

\subsection{1.- LA LEYENDA de El Dorado.}

La búsqueda de oro, del que la expansiva economía de la Europa renacentista tenía necesidad, fue uno de los móviles esenciales de la empresa descubridora de Colón. Así, durante las tres primeras décadas de la conquista americana se explotó el oro de las Antillas, sometiendo a los indígenas a trabajo forzado en el lavado de arenas auríferas; más tarde, conforme avanzaba la conquista, el anhelo de seguir

7 La película original de Saura exhibida en sala es bastante más larga (su duración es, en concreto, de 151
minutos) que la versión "cortada" disponible en formato VHS -el utilizado en el presente análisis-. Sólo tras el minutos) que la versión "cortada" disponible en formato VHS -el utilizado en el presente análisis-. Sólo tras 
encontrando metales preciosos ${ }^{9}$ en las Indias occidentales cristalizaría en un rastreo incansable del mítico "El Dorado".

Esta afanosa búsqueda de oro en América responde a una doble finalidad: en primer lugar, resulta evidente que la riqueza, la abundancia de metal, se interprete como el premio o trofeo que reconozca los múltiples riesgos y penalidades padecidos en tierras desconocidas. Pero a estas motivaciones económicas se une el aspecto mítico de la propia búsqueda ${ }^{10}$, en función del cual América permite el feliz reencuentro en su territorio con esa Edad de Oro ${ }^{11}$ perdida en el Viejo Mundo y que el europeo del Renacimiento desea recobrar ${ }^{12}$.

La bibliografía generada por la leyenda de El Dorado es extraordinariamente amplia y, en ocasiones, las fuentes no demuestran unanimidad en los datos que aportan, circunstancia ésta que dificulta la labor de ofrecer una definición exacta de la misma. En vista de ello, optamos por enumerar a continuación las características del mito que sí parecen suscitar posturas homogéneas:

Los europeos oyen hablar por primera vez de la leyenda indígena sobre "el hombre dorado" en un momento indeterminado comprendido entre la segunda y cuarta décadas del siglo XVI.

8 Entre los mitos aplicados al continente americano pueden citarse, entre otros, el de la Atlántida, las Hespérides, Orfis y Tarsis, Omagua, Jauja, el País de la Canela, el País de Meta, el País de Cucaña, el Imperio del Padre Juan, las Siete Ciudades de Cíbola, la Ciudad de los Césares, Cipango, el Tesoro del Rey Blanco, la Fuente de la eterna juventud (o el elixir de la larga vida), los gigantes, los grifos, los dragones, los peces voladores, etcétera, además de los que se describen y analizan a continuación.

9 De sobras es sabido que la búsqueda de oro, de riqueza en general, ha constituido una obsesión para el hombre a lo largo de la Historia. La mitología grecolatina nos habla del rey frigio Midas, que solicitó al dios Dioniso que todo lo que su cuerpo rozase se convirtiera en oro, y del periplo de Jasón y sus Argonautas en procura del vellocino de oro. El ciclo artúrico, que gozó de una amplísima difusión durante la Edad Media, giraba en torno al hallazgo de un misterioso cáliz de oro, el conocido como "Santo Grial". En la propia conquista de América, la superación de la "fiebre del oro" darí paso a la explotación intensiva de los filones quista de Améc argentiferos en el descubrimiento de este menadá Alaska a finales de siglo (El filme La quimera del oro-The golden rush, 1925-, de Charles Chaplin, tiene como trasfondo dicha búsqueda de oro en Alaska). Por último, en el siglo XX el interés se ha centrado en la detección de petróleo, metaforizado como "oro negro".

10 La idea del oro con un valor simbólico más allá de su valor material procede de la expedición de Jasón para conquistar el vellocino de oro y las aventuras de los Caballeros del Rey Arturo tras el cáliz del Santo Grial. En lo que al vellocino se refiere, éste no sólo representa la condición necesaria para que el héro recuGrial. En lo que al vellocino se reflere, éste no sólo representa la condición necesaria para que el heroe recupere su dercho que consecución supone todo un viaje iniciático jalonado de pruebas de perfeccionamiento personal. Por su parte en el Santo Grial se conjugan el valor material de la joya y el secreto de la inmortalidad que ésta encierra.
11 Con este nombre se conoce el primero de los períodos míticos en los que la Antigüedad grecorromana con el poeta griego Hesíodo a la cabeza- dividía la historia del mundo. Esta Edad de Oro transcurrió bajo e reinado de Crono/Saturno y se caracterizaba por ser una época idílica en la que predominaban la inocencia, el bienestar y la abundancia sin trabajo. El hombre del siglo XVI, obsesionado con el redescubrimiento y la vuelta al mundo clásico, retoma este ideal grecolatino y lo proyecta sobre la recién descubierta y virgen America en un intento allaba sumida.

12 Para un análisis detallado de esta cuestión, vid. AíNSA, F.: De la Edad de Oro a El Dorado. Génesis del discurso utópico americano. México D. F., Fondo de Cultura Económica, 1992, págs. 81-130. 
La ceremonia de El Dorado, celebrada presumiblemente en la laguna de Guatavita, respondía al rito más importante observado por los indios chibchas (asentados en el altiplano de la cordillera oriental de la actual Colombia). Dicha ceremonia consistía en una ablución ritual que tenía lugar al amanecer. El cacique impregnaba todo su cuerpo con un ungüento sobre el que se espolvoreaba oro molido13. Junto a los principales hombres de la tribu se dirigía en una balsa de junco hasta la mitad del lago; allí, al surgir el sol sobre el horizonte, el jefe se sumergía totalmente en el agua, al tiempo que los sacerdotes arrojaban a la laguna objetos de oro ${ }^{14} \mathrm{y}$ piedras preciosas, principalmente esmeraldas.

Paulatinamente la geografía de la zona fue absorbiendo el mito de "el hombre dorado", de forma que la cartografía identificó primero El Dorado con el lago Parime y más tarde con la ciudad de Manoa ${ }^{15}$. Entre las principales expediciones organizadas para su búsqueda cabe citar las de Jiménez de Quesada (1537 y 1569), Hernán Pérez de Quesada (1538), Felipe von Hutten (1535-1538) ${ }^{16}$, Ursúa y Lope de Aguirre (1560-1561), Fernández de Serpa y Maraver de Silva (1569), Antonio de Berrio (1584, 1587 y 1590), el inglés sir Walter Raleigh (1595 y 1616) y Fernando de Berrio (1597-1608), entre otras. El gobernador de Guayana enviaría otras dos a finales del siglo XVIII, las cuales pondrían fin a la leyenda.

Los cronistas Fernández de Oviedo, Cieza de León y Juan de Castellanos y los conquistadores Gonzalo Pizarro, Jiménez de Quesada y Benalcázar constituyen las fuentes primarias de la leyenda de El Dorado ${ }^{17}$. No obstante, a éstos deben sumarse Francisco Vázquez, Pedrarias de Almesto y Custodio Hernández, componentes y supervivientes de la expedición comandada primero por Pedro de Ursúa y después por Lope de Aguirre.

Cuando los europeos son informados del ritual anteriormente descrito, los indios que lo celebraban habían sido ya exterminados por tribus vecinas. Así pues,

13 Antropológicamente se sabe que es costumbre entre las tribus amazónicas pintar íntegramente sus cuerpos desnudos con barro rojo, el conocido como "genipapo negro" -un tinte extraído de las plantas- y "achote", un uso que todavía en la actualidad se sigue practicando y que hace más verosímil la ceremonia del cacite", un uso que todavia en la actualidad se sigue practicando y que hace más verosimil la ceremonia del cacique chibcha. Cf. HEMMING, J.: En busca de El Dorado. Barcelona, Ediciones del Serbal, 1983, págs. 135-
136.

14 Los chibchas obtenían mediante trueque por la sal gran cantidad de oro explotado por los pueblos que habitaban a orillas de las cordilleras Oriental y Central del actual territorio colombiano, con lo que satisfacían las necesidades de su industria suntuaria. Hábiles orfebres, realizaban cuentas huecas y figuras estilizadas decoradas con motivos de alambre o cintas de oro retorcidas. Además, sus jefes y sacerdotes se cubrían el cuerpo con finísimas láminas de oro, otro elemento que podría haber influido en la configuración de la leyenda de El Dorado.

15 Vid. ROJAS MIX, M.: América imaginaria. Barcelona, Lumen, 1992, págs. 60-63, y AíNSA, F.: Op. Cit., pág. 122.

16 Von Hutten, en busca de El Dorado, encontró el país de los omagua (tribu amerindia) en 1541. Tomó la región por EI Dorado, algo que contribuyó a mantener vivo el mito. En el siglo XVIII la expedición de Fritz puso fin a la identificación de Omagua con el mítico territorio dorado.

17 Al menos, así lo defiende John Hemming. Cf. HEMMING, J.: op. cit., pág. 139. 
el reino de El Dorado ya es pasado cuando ingresa en el imaginario colectivo europeo. Sin embargo, la búsqueda de oro con la doble finalidad que se ha señalado en líneas previas provocó que el mito reapareciera constantemente en el continente americano, dando lugar a un El Dorado ubicuo o errante, o bien reactualizado con nombres diversos 18 .

En la película de Carlos Saura, esta fábula adquiere una importancia fundamental, como es posible deducir ya desde su propio título, El Dorado. La presencia de este mito en el filme aparece tratada desde una doble perspectiva, la iconográfica y la temática propiamente dicha.

En lo que al tratamiento iconográfico de El Dorado se refiere, resulta indiscutible el hecho de que los fotogramas iniciales del largometraje están inspirados en uno de los grabados que incluye De Bry ${ }^{19}$ en su Enciclopedia Iconográfica de América, concretamente en el titulado "De cómo agasaja el emperador de Guayana a sus nobles cuando de invitados los tiene" 20 . En él se observa a uno de los convidados del emperador siendo preparado adecuadamente para la celebración de un banquete: el invitado, desprovisto de sus vestiduras, es untado por uno de los criados con la sustancia depositada en el recipiente que sostiene en la mano, en tanto que el otro sirviente lo recubre con una fina capa de oro en polvo que sopla a través de una caña 21.

Saura recurre a este grabado para plasmar cinematográficamente la celebración del ritual protagonizado por el cacique del pueblo chibcha en la laguna Guatavita. Así, en el fotograma de apertura del filme, puede observarse al líder chibcha terminando de ser recubierto con los pigmentos áureos que uno de sus súbditos le aplica soplando a través de una fina caña, unos pigmentos de oro que se

18 Vid. AíNSA, F.: op. cit., págs. 123-124.

19 Theodor De Bry nació en Lieja en 1528. Ejerció su profesión de grabador -en la que desempeñó un notable influjo el maestro parisino de grabado decorativo Esteban Delaune- primero en Estrasburgo y después en Francfort, donde en 1590 presentaba los primeros libros de un volumen que más tarde pasaría a llamarse Tesauro de los viajes a las Indias occidentales y orientales. Tras su muerte en 1598 serían sus hijos, Juan Teodoro y Juan Israel, quienes se encargaran de la continuidad del taller así como del resto de libros de la magna obra emprendida por su padre.

20 La presencia de este grabado en el libro en el que Carlos Saura publicó el guión original de El Dorado así como sus propias reflexiones acerca del rodaje viene a corroborar este hecho. Cf. SAURA, C: op. cit., pág. 173 21 El texto que acompaña al grabado dice así: "Son los habitantes de la región de Guayana, al igual que sus vecinos, muy dados a la bebida y superan en su afición a embeodarse a todas las demás naciones. Cuando el emperador ofrece un banquete a sus funcionarios y nobles, los invitados todos son desvestidos por sus criados hasta quedar desnudos, y untados de pies a abeza con un bálsamo blanco, y rociados luego por sus criados hasta quedar desnudos, y untados de pies a cabeza con un bálsamo blanco, y rociados luego con una arena aurifera, clara y pura que soplan por unas cañitas y que se quedan pegadas en el bálsamo,

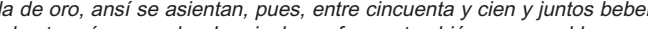
y comen siete y ocho días seguidos hasta más no poder. Los ingleses fueron también en una aldea cuyo cacique, de nombre Toparimaca, tenía de invitado a un cacique forastero, y estaban ambos sentados en una hamaca brasileña, que es una cama, y dos mujeres les servían la comida y les escanciaban la bebida sin cesar, y cada uno dellos había de brindar por el otro, bebiendo tres copas seguidas. Su poción está hecha y preparada del jugo de varias hierbas en que ponen toda suerte de especias y condimentos picantes y guárdanlo en vasijas de barro cocido de diez o doce toesas de altura. 
adhieren al cuerpo del jefe por medio del ungüento o resina contenido en el recipiente que sujeta el otro súbdito y que se supone aplicado previamente. A diferencia de De Bry, el cineasta no dispone a los actores en la posición frontal en que el grabador había situado a sus figuras, sino que los coloca lateralmente. El líder conserva el aderezo de plumas con que De Bry había adornado al invitado en su ilustración, y añade un faldellín del que el personaje grabado carecía. Tras él aparecen las tranquilas aguas sobre las que reposa una balsa de madera. Una vez cubierto completamente de oro, como si de una estatua de dicho metal se tratara, el cacique chibcha camina por la orilla hasta alcanzar la balsa, a la que se sube; los remeros lo dirigen entonces hacia el centro de las aguas. En definitiva, el director aragonés se sirve de esta supuesta costumbre guayanesa que De Bry recrea en su obra para construir la iconografía fílmica de uno de los mitos indígenas que mayor calado provocó en el imaginario colectivo de los descubridores y conquistadores del Nuevo Mundo.

En otro orden de cosas, en la película de Saura se aprecia nítidamente cómo en la búsqueda de El Dorado la expedición capitaneada por Pedro de Ursúa evoluciona progresivamente desde el ánimo exacerbado que provoca la sólida y ciega confianza en la existencia del "reino de oro" (los gritos de "¡A por El Dorado!" expelidos por las huestes como réplica a la arenga que les dirige Ursúa en los primeros minutos del filme así parecen confirmarlo) hasta la certeza de que lo que buscaban era tan sólo un sueño que, como tal, se ha desvanecido. Dicha progresión se escaIona en una serie de circunstancias entre las que cabe destacar la reflexión de Aguirre cuando el metraje no está aún muy avanzado (“iPara qué adentrarse en esta selva inhóspita! ¿No son nuestras vidas más importantes que este esfuerzo inútil?”), la conciencia de los propios expedicionarios de que la jornada en la que están inmersos es una estratagema política (el diálogo entre Pedrarias, cronista de la expedición, y Ursúa lo corrobora: “- Los hombres empiezan a inquietarse y eso es peligroso, Pedro... Se habla de que El Dorado no es para nosotros y que esta expedición sólo ha sido una patraña para alejar a unos españoles peligrosos del Perú...; - Eso es en parte verdad... El virrey se ha quitado un peso de encima alejando de su lado a sus capitanes más rebeldes...") y el deseo de alguno de los integrantes de abandonar la empresa (por ejemplo, el alcalde Alonso de Montoya se expresa en los siguientes términos: "Yo creo, señor, que sería una locura continuar la expedición en estas circunstancias. Mejor sería volver por donde vinimos que morir en estas tierras, en donde sólo sufrimientos y crueldades nos esperan...").

Y como colofón, las paradójicamente lúcidas palabras del ebrio Alonso de Esteban, guía de la expedición: "¡Y el sueño de ayer se va desvaneciendo! ¿No iremos en pos de un fantasma?".

Sea como fuere, mito o realidad, la noticia del ritual chibcha causó una profunda impresión en el colonizador europeo y ello revirtió en el tratamiento de la ico- 
nografía de América. De Bry en su grabado y Saura en su largometraje dan lugar a sendos iconos del legendario "hombre dorado"; ambos constituyen una imagen del Nuevo Mundo tamizada por la visión del europeo, pertenezca éste al siglo XVI o al XX.

\subsection{2.- AmAZONAS, SIRENAS Y ACÉfalos.}

Transcurridos escasos días desde el comienzo de la expedición, el ya citado Alonso de Esteban fantasea en la cubierta del bergantín teniendo como espectadores a Lope de Aguirre y a la hija de éste, Elvira. La niña escucha con gran atención las palabras del guía, quien, en su relato, hace alusión a las amazonas, las sirenas y los acéfalos.

Así pues, la referencia que se hace en El Dorado a estos seres míticos es simplemente auditiva, no visual. Ahora bien, el hecho de que no haya imágenes no implica necesariamente la ausencia de iconografía, pues si ésta se entiende como "descripción de imágenes" dicha descripción queda incluida en las palabras de Alonso de Esteban 22 , circunstancia ésta que propicia que el espectador evoque mentalmente esas imágenes que los fotogramas del filme no recogen.

Por otra parte, no debe obviarse el enriquecimiento que supone para la imagen de América registrada en la película de Saura el hecho de que se haga mención de "amazonas", "sirenas" y "acéfalos", mitos del acervo occidental que los europeos exportan al Nuevo Mundo, dando lugar a una "América imaginaria" en la que la realidad y la fantasía se superponen constantemente.

\section{A) LAS AMAZONAS.}

El mito de las amazonas se remonta a la Antigüedad Clásica, cuya tradición las presenta como un pueblo de mujeres cazadoras y belicosas descendientes de Ares, dios de la guerra. Su reino parece situarse en Escita (al Sur de la actual Rusia, o incluso Ucrania), en Temiscira, al Norte de Asia Menor, o tal vez en Tracia. Rechazaban la autoridad de los hombres y se gobernaban a sí mismas, con una reina a su frente. Tan sólo se unían ocasionalmente con hombres de tribus vecinas para reproducirse: a los hijos varones los mataban o los sometían a la esclavitud; a las mujeres las educaban en el arte de la guerra y les amputaban el seno derecho

22 El guía de la expedición aporta los siguientes datos: “(...) Y hay sirenas juguetonas, gordinflonas y tetudas; las llaman manatíes y lloran como niñas... iY hay hombres sin cuello! (...) que tienen la cara aquí... (señalándose el pecho y dibujando sobre él). Los ojos, la nariz y la boca... iY las amazonas!... iEso es!... En el río Trombetas nos atacaron las indias guerreras... jSon tan membrudas y andan desnudas, en cueros! (...) Cada una de ellas hacía tanta guerra como diez indios... iLa reina de las amazonas se llamaba Calafia!, y su pais, „California!". 


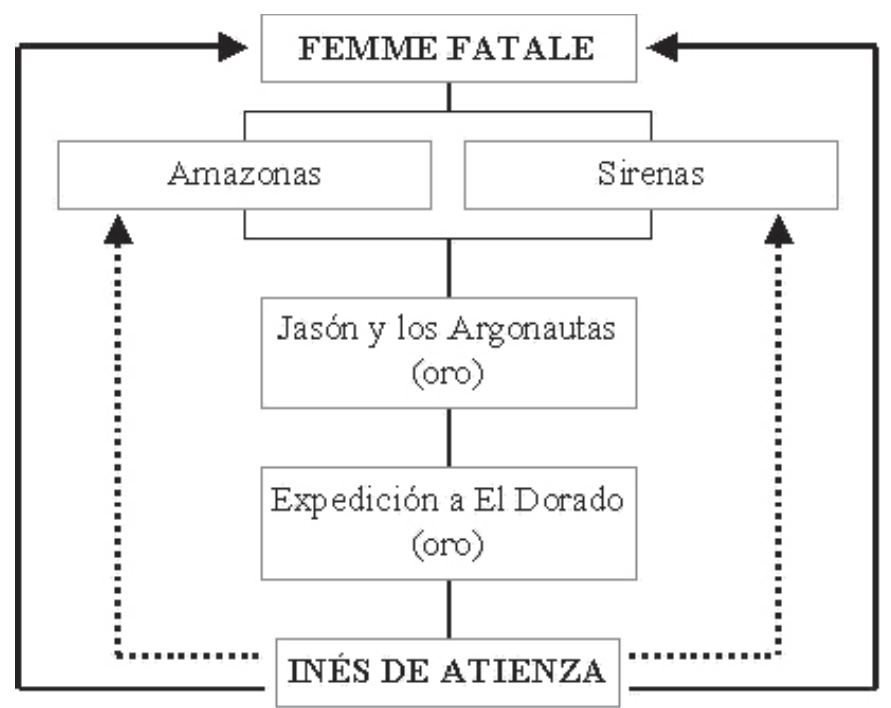

para facilitarles la práctica del tiro con arco. Diversas leyendas han transmitido el nombre de algunas de ellas: Hipólita, Pentesilea -ambas reinas de las amazonas- $y$ Antíope, hermana de la primera23.

Este mito sobrevive durante la Edad Media, ocupándose de él, entre otros, algunos enciclopedistas medievales cristianos (Rabano Mauro, Honorio de Autum, Vicente de Beauvais y Tomás de Cantimpré), Alfonso X el Sabio en el libro "Jueces" de su Estoria, Marco Polo en su Libro de las cosas maravillosas de Oriente, Mandeville en el Libro de las maravillas del mundo y la conocida como Carta del Preste Juan. También algunos libros de caballerías del siglo XVI, como es el caso de Las sergas de Espladián, hijo de Amadís, recuperaron la figura de las amazonas ${ }^{24}$.

En el proceso de descubrimiento y conquista del cuarto continente llamó poderosamente la atención de los europeos el mando ejercido por las mujeres de determinadas tribus y la participación de indias provistas de arco y flechas en combates. De estas mujeres guerreras, independizadas de los hombres y que tantas concomitan-

23 La descripción del mito aparece recogida con todo detalle en GRIMAL, P. (1965): Diccionario de mitología griega y romana. Barcelona, Labor, 1984, págs. 24b-25a.

24 Un bonito comentario sobre el mito de las amazonas durante la Edad Media es el que incluye RAMíREZ ALVARADO, Ma M.: Construir una imagen. Visión europea del indígena americano. Sevilla, CSIC, 2001, págs. $111-113$ 
cias guardaban con las amazonas dan cuenta, por ejemplo, Cristóbal Colón en su Diario del primer viaje cuando se refiere a las habitantes de la isla Martinino; Hernán Cortés en la cuarta de sus Cartas de Relación al hablar de otra zona insular en la provincia de Ciguatán; el dominico Gaspar de Carvajal da noticia de las tribus de mujeres "Coniupuyara", capitaneadas por una líder llamada "Coñori”; Jerónimo de Ortal encontró tribus con régimen matriarcal gobernadas por la reina "Orocomay"; Hernando Pérez siguió el rastro de las mujeres guerreras que tenían por soberana a "Jarativa". Asimismo, aportan referencias Alonso de Rojas, cronista de la expedición del portugués Pedro Texeira Molato, Cristóbal de Acuña en Nuevo descubrimiento del Gran Río de las Amazonas y Ulrico Schmidl en Relatos de la conquista del Río de la Plata y Paraguay (1534-1554)25.

De esta forma, cuando los europeos llegan a América se produce la confluencia de, al menos, tres factores en lo que al mito de las amazonas se refiere:

En primer lugar, la constatación de la existencia de tribus indígenas con sistema matriarcal y de condición guerrera, tal y como viene comentándose.

El establecimiento de un paralelismo entre el modus vivendi de tales tribus y los datos aportados por la tradición sobre las amazonas de la Antigüedad Clásica.

La puesta en conocimiento del mito inca de las "Vírgenes del sol", que vincularon con el mito clásico en función del aislamiento femenino con respecto de los hombres que se registraba en ambos.

Así pues, esta triple circunstancia crea el caldo de cultivo perfecto para que conquistadores y cronistas traspongan las amazonas míticas presentes en el imaginario colectivo occidental a la realidad del Nuevo Mundo, creando con ello una América fantástica que responde al deseo europeo de una nueva oportunidad -en el más amplio sentido de la palabra- en una nueva tierra.

Sumamente elocuente resulta a este respecto el hidrónimo del río más largo del continente americano, el "Amazonas", bautizado así por ser en sus orillas donde estos primeros europeos creyeron encontrar a las belicosas mujeres sobre las que habían leído en Homero y Heródoto. Algo similar sucede con la imagen alegórica de América, con una iconografía extraordinariamente cercana a la que se atribuye a la amazona mítica 26 , siendo el punto de encuentro entre ambas la fisonomía y atributos de la mujer indígena de tierras americanas.

En El Dorado de Saura llama la atención un fragmento de la intervención de Alonso de Esteban anteriormente reproducida en la que éste afirma que la reina de

25 Vid. RAMÍREZ ALVARADO, Ma M: Op, Cit., págs. 113-121.

26 La imagen de América queda alegorizada por Cesare Ripa en el siglo XVI. Ripa alegoriza el cuarto continente como una mujer semidesnuda, de largos cabellos adornados por una corona de plumas, y provista 
las amazonas se llamaba "Calafia" y su país, "California". Este dato permite deducir que Saura hace a su personaje deudor de la tradición caballeresca tan en boga durante el Quinientos español, en concreto de la ya mencionada Las sergas del muy valeroso y esforçado caballero Espladián, hijo de Amadís (1511), continuación del célebre Amadís de Gaula, novelas ambas de Garci Rodríguez de Montalvo. En dicha obra, al frente de las aguerridas mujeres a las que se enfrenta Espladián se encuentra la reina "Calafia" o "Celafia", descendiente de la Hipólita mitológica; todas ellas habitan la isla de "California", situada en un lugar impreciso de las Indias cercano al Paraíso terrenal. Por tanto, el personaje de Alonso de Esteban constituye un ejemplo muy evidente de cómo el descubrimiento del nuevo continente conduce a estos primeros europeos al recurso a la fantasía y la invención como estrategia para intentar comprender una cultura, la americana, extraña y misteriosa para ellos ${ }^{27}$.

\section{B) LAS SIRENAS.}

Las palabras del guía de la expedición ponen de manifiesto otra de las asimilaciones que se derivaron de la puesta en contacto entre el acervo mítico grecolatino y esa nueva y enigmática realidad con la que los europeos se encuentran en América. Se trata en este caso de la afirmación de la existencia de sirenas en el nuevo continente a partir de la identificación en aguas americanas de un animal hasta entonces desconocido por los europeos, el manatí28.

Indudablemente, este animal fue confundido por los primeros expedicionarios de América con el monstruo mítico que ellos conocían como "sirenas"29, identificación ésta en la que debió de influir también el mito prehispánico inca de las "mujeres-pez" 30 .

Dicha confusión puede observarse en textos como el Diario de Cristóbal Colón (que habla de unas feas sirenas que salían del mar en la zona caribeña), en

de arco, flecha y carcaj al hombro, entre otros detalles (vid. RIPA, C.: Iconología. Madrid, Akal, 1996, págs. 108-109). Todos estos atributos son comunes tanto a las descripciones iconográficas de las amazonas como a la indumentaria característica de las indígenas americanas. El vínculo iconográfico que se establece entre América y el arco y la flecha llega hasta el punto de que la deidad clásica femenina asociada al Nuevo Mundo sea Ártemis/Diana, por ser éstos también los atributos que la caracterizan.

27 La obra en la que se publicó el guión del filme incluye también diversos dibujos y bocetos llevados a cabo por el realizador oscense durante el rodaje. Resulta muy curioso uno de ellos en el que Saura ha plasmado una amazona con tres pechos. Cf. SAURA, C.: op.cit., pág. 46.

28 El manatí es un mamífero herbívoro del orden de los sirenios que vive en los ríos de la zona tropical de África y América; de cuerpo macizo, puede llegar a alcanzar tres metros de longitud y hasta 500 Kilogramos de peso.

29 Según la mitología clásica, las sirenas eran un monstruo marino con cabeza y senos de mujer y cuerpo y alas de ave; su representación iconográfica sufrió una notable transformación durante la Edad Media, quedando convertidas en criaturas fantásticas con cabeza y torso femeninos y cola de pez.

30 Según la mitología andina, Tanupa (dios del fuego) recorrió las tierras próximas al lago Titicaca en labor civilizadora enviado por Viracocha (dios creador) y fue torturado y sentenciado a muerte por mantener relacivilizadora enviado por Viracocha (dios creador) y fue torturado y sentenciado a muerte por mantener rela-
ciones sexuales con sus hermanas Qesintuu y Umantuu, sirenas o nereidas que habitaban en dicho lago. 
las Décadas del Nuevo Mundo de Pedro Mártir de Anglería y en la Historia general y natural de las Indias de Gonzalo Fernández de Oviedo y Valdés, entre otros. Su amplia difusión consagró a la sirena como motivo frecuente en las representaciones iconográficas del Nuevo Mundo 31 .

\section{C) Los ACÉFALOS.}

Es el tercero de los mitos occidentales que Alonso de Esteban traslada al continente americano en el filme. De estos monstruos acéfalos habían hablado Heródoto, Plinio y San Isidoro de Sevilla (quienes les dieron el nombre de "blemmyas", voz procedente del griego), además de San Agustín, Marco Polo, Mandeville e, incluso, Shakespeare. En su obra El descubrimiento del grande, rico y bello imperio de Guayana, sir Walter Raleigh mencionaba una estirpe a la que llamaba "ewaipanomas", que vendrían a ser la versión americana de las "blemmyas" medievales.

En conclusión, el personaje de Alonso de Esteban en el filme El Dorado ejemplifica esa imagen de América que construyen los europeos a partir de la fusión de su imaginario colectivo occidental y la nueva e ininteligible realidad con la que entran en contacto en los territorios recién descubiertos. En este sentido, mitos clásicos y bestiarios medievales resultan de gran utilidad a la hora de interpretar estos fenómenos inéditos que conquistadores y cronistas contemplan en tierras americanas.

No obstante lo hasta aquí señalado, dichos mitos -al menos en lo que a las amazonas y las sirenas se refiere- adquieren implicaciones más profundas en la película de Saura, según se podrá comprobar en epígrafes sucesivos.

\subsection{3.- LOPE DE AGUIRRE COMO MITO.}

En epígrafes previos se han venido analizando determinados mitos (El Dorado, las amazonas, las sirenas, los acéfalos) desde la perspectiva de relatos populares y literarios en los que intervienen seres sobrehumanos que transponen acontecimientos históricos o en los que se proyectan ciertas estructuras subyacentes a la organización social; se propone a continuación la descripción y análisis de otro

Esta leyenda gozó de gran fortuna y se convirtió en motivo recurrente en la iconografía andina, destacando las representaciones de las portadas de antiguas iglesias y otras construcciones precolombinas.

31 En este sentido, cabe mencionar las sirenas que De Bry incluye en su Enciclopedia Iconográfica de América; son cuatro los grabados en los que aparece esta criatura fantástica: los que abren los libros cuarto y decimotercero y los titulados "Descubrimiento del Mar de Magallanes" y "No puedo aquí pasar en silencio aquella extraña creatura...".

32 Entre estas dos versiones filmicas de las peripecias del vasco de Oñate, quizá la que mayor peso conceda a la figura de Aguirre sea la película alemana. De hecho, el propio título del filme anuncia ya el protagonismo absoluto del personaje interpretado por Klaus Kinski en esa atmósfera austera, fría y de escaso diá- 
mito que aborda el filme de Carlos Saura, el del propio Lope de Aguirre, en esta ocasión desde el punto de vista del poder de fascinación suscitado por este personaje histórico en función de sus peculiares características.

Lope de Aguirre (Oñate, 1518) se trasladó desde las Antillas a Perú en 1537, donde se vería envuelto en las guerras entre pizarristas y almagristas y más tarde entre las tropas reales y los insurrectos. Tuvo problemas con la legalidad y, para formalizar su situación, se alistó en la exploración en busca de El Dorado encomendada a Ursúa. Dirigió la sublevación que puso fin a la vida de éste y fue eliminando sucesivamente a sus compañeros más destacados. Tras rebelarse contra la monarquía de Felipe II -tal y como lo atestigua la famosa carta dirigida al soberano español-, el propio Aguirre se hizo proclamar rey por el resto de los expedicionarios. Junto a ellos se dirigió hacia Isla Margarita, engrosando en esta nueva travesía la suculenta lista de crímenes que, a la postre, le han valido un lugar en la Historia. Y es que, desde que se embarcara el 26 de septiembre de 1560 a las órdenes de Ursúa hasta su muerte -acaecida el 27 de octubre de 1561- el vasco asesinó u ordenó asesinar a 72 personas, entre ellas a su propia hija (hecho que en el filme que en las presente líneas nos ocupa queda reflejado en la pesadilla premonitoria que sufre Aguirre).

Tras saquear diversas poblaciones insulares, se adentró en el continente, donde venció a las tropas reales en las ciudades de Nueva Valencia, Mérida y Tocuya. Reorganizadas dichas tropas reales cerca de Barquisimeto (Venezuela), el gobernador dictó un bando por el que se ofrecía una amnistía a quienes desertaran de las filas de Aguirre; ante esta promesa, los expedicionarios abandonaron a su capitán, no sin antes asestarle dos arcabuzazos y amputar a su cadáver la cabeza y ambas manos.

Resulta llamativo el hecho de que en las películas que abordan la expedición a El Dorado de 1560-1561 (El Dorado estuvo precedida por Aguirre, la cólera de Dios -Aguirre, der Zorn Gottes, 1972-, del director alemán Werner Herzog), dicha empresa y la propia fábula del hombre y del reino de oro queden relegados a un segundo plano en tanto que la atención la acapara uno de los expedicionarios, Aguirre. Así pues, tanto Herzog como Saura se proponen en sus respectivos filmes analizar la personalidad de este cruel y sanguinario personaje ${ }^{32}$ al que la jornada de EI Dorado consagró como mito en función de dos factores:

Un carácter violento y colérico que le condujo a perpetrar múltiples crímenes y le valió los sobrenombres de "el loco" o "la cólera de Dios".

Su afán independentista con respecto de la Corona española, que le lleva a rebelarse contra Felipe II y proclamarse "Príncipe del Perú y de Chile". La misiva

logo que caracteriza al largometraje de Herzog, en el que puede llegar a afirmarse que la expedición a E Dorado queda reducida a mera excusa, simple trasfondo. 
TRASLADAN A AMÉRICA

\begin{tabular}{|c|c|}
\hline Europecs \\
del Renacimiento \\
(alimentado en la Tradic ión Clásica \\
y Medieval)
\end{tabular}

\section{TRASLADAN A AMÉRICA}

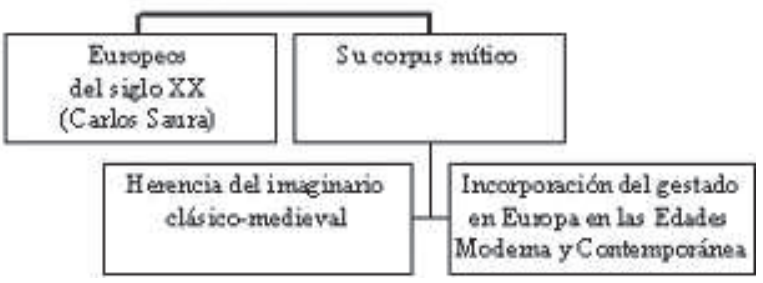

remitida al Austria ha sido interpretada como la primera declaración de independencia americana, y algunos estudiosos nacionalistas vascos han intentado ver en Aguirre una suerte de mito libertador.

No cabe duda de que la rebelión de Lope de Aguirre contra Felipe II convirtió esta expedición a El Dorado en uno de los episodios más conocidos de la conquista del Nuevo Mundo e hizo del de Oñate una figura mítica que ha fascinado a numerosos literatos. Walter Scott, Giovanni Papini, Sainte Beuve, Uslar Pietri, Pío Baroja y Miguel de Unamuno, entre otros, hicieron referencia a él en sus obras. Asimismo, ha inspirado las novelas de Ciro Bayo (Los marañones, 1913), Ramón J. Sender (La aventura equinoccial de Lope de Aguirre, 1968) y del venezolano Otero Silva (Lope de Aguirre, príncipe de la libertad, 1979).

La representación cinematográfica del mítico Aguirre en la película de Saura lo convierte en un icono en el que se conjugan simultánea y paradójicamente la imagen de la conquista (la insistencia en armaduras y armas ya desde los propios carteles del filme así lo corrobora, presentándose la empresa americana como una nueva Reconquista en la que los musulmanes han sido sustituidos por los indígenas) y la imagen de la libertad y la independencia de América. 


2: artículos Angélica García Manso

\section{2.- Los TÓPICOS.}

El descubrimiento de América y, por consiguiente, el encuentro con tierras y gentes exóticas, generó inevitablemente un conjunto de imágenes sobre estas nuevas latitudes cuya aparición recurrente convirtió en imágenes estereotipadas o clichés del Nuevo Mundo. En El Dorado también pueden detectarse algunos de estos lugares comunes, los cuales pueden ser clasificados en las categorías que a continuación se proponen.

\subsection{1.- Tópicos relacionados con la Naturaleza.}

En el filme de Saura el recurso a la palmera como símbolo iconográfico de América es sustituido por una vegetación frondosa y exuberante que da lugar a una selva indómita de la que incluso se refiere la existencia de plantas carnívoras. La humedad, que putrefacta la madera de las embarcaciones, y el agua, tanto la fluvial como la lluvia amazónica, también son elementos constantes a lo largo del metraje (debe tenerse en cuenta que, de los llamados cuatro elementos, el agua es el que tradicionalmente ha venido asociándose con este continente ${ }^{33}$ ).

En cuanto a la fauna, es posible apreciar una evidente oposición entre el caballo -animal europeo por antonomasia desde el punto de vista iconográfico-, de nula utilidad en la selva, $y$ algunas especies americanas como tortugas de gran tamaño y guacamayos. En este sentido, llama especialmente la atención la insistencia en anacondas y otros tipos de serpientes, algo que remite inexorablemente a esa idea de América como "infierno" que paulatinamente fue sustituyendo a aquella otra primera impresión del Nuevo Mundo como "paraíso" (así lo demuestran las palabras del personaje de Fernando de Guzmán:

"Dios mío, ¿qué locura nos ha entrado en estas tierras? Todo es aquí muerte y destrucción".

En definitiva, en El Dorado la naturaleza del cuarto continente se ajusta a esa tendencia que, desde las primeras representaciones de América, ha procurado incidir en la alteridad que el Nuevo Continente suponía para el Viejo; de ahí que se registre un ámbito natural exótico capaz de provocar el mayor contraste posible con el europeo.

33 Tanto es así que, desde presupuestos iconográficos, la divinidad grecolatina masculina que se asocia al continente americano es Poseidón/Neptuno, por su calidad de dios de los mares y protector de los navegantes 


\subsection{2.- LAS MASACRES DE INDIOS.}

La armada de Ursúa detiene su navegación para penetrar en un poblado indígena. Aguirre entra en una de las cabañas y, allí, hacinados sobre el suelo, descubre una treintena de cadáveres pertenecientes a hombres, mujeres y niños indios asesinados mediante tiros de arcabuz y flechas de ballesta, un dato que indica claramente que han perecido a manos de españoles.

La película de Saura no obvia, pues, esta cruenta circunstancia que caracterizó la conquista española de América. La larga enumeración de matanzas, destrucciones, barbaries y otros agravios y ofensas padecidos por los indígenas que Fray Bartolomé de Las Casas recogió en su Brevísima relación de la destrucción de las Indias (1552) desempeñó un papel fundamental en la configuración de la Leyenda Negra de la colonización española de América; las potencias europeas enemigas de la Corona de Castilla hicieron del opúsculo del dominico todo un tópico acerca de la criminalidad hispana en las nuevas tierras. Así pues, las masacres de indios pasaron a engrosar el listado de arquetipos sobre la América de la Conquista. El hecho de que el director aragonés registre este tópico en su filme ratifica el común rechazo por parte de españoles y latinoamericanos de esa realidad histórica que, desde el punto de vista iconográfico, han abordado, por ejemplo, numerosos pintores de Iberoamérica adscritos al movimiento muralista.

\subsection{3.- El CANibalismo.}

En otra de sus incursiones en tierra la expedición descubre un poblado indio. Mientras el resto de la comitiva registra las chozas buscando alimentos, el cura Henao se detiene ante una especie de adoratorio que hay bajo el techado de una cabaña -en una tabla están pintados el sol y una figura de hombre; en otra, la luna y una representación femenina. Cráneos y otros huesos demuestran que aquel lugar es un altar de sacrificios humanos. El sacerdote, al comprender que se trata de una tribu de antropófagos, se santigua horrorizado. Así pues, El Dorado también se hace eco de esta peculiaridad de determinados colectivos indígenas amerindios que el hombre europeo convirtió en rasgo generalizado del Nuevo Mundo y, por consiguiente, en atributo iconográfico arquetípico de América ${ }^{34}$.

34 Efectivamente, el del canibalismo o antropofagia se convirtió en uno de los tópicos iconográficos más reiterados en las representaciones que los europeos realizaron de América. Quizá la alusión gráfica más temprablicadas en 1505. Una década más tarde, este motivo se incluiría ya en una representación cartográfica. publicadas en 1505. Una década más tarde, este motivo se incluiria ya en una representación cartográfica. Asimismo, de este fenómeno cultural se ocuparían también autores como A. Thevet, J. de Léry, H. V. Staden,
Honorio Philopono, Albert Eckhout, etcétera. El propio De Bry dedica numerosos grabados a este asunto, entre los que destacan especialmente los incluidos en el Libro Tercero, que describen las costumbres de los 


Q: artículos Angélica García Manso

\subsection{4.- LA INDUMENTARIA INDIGENA.}

La imagen del indio es uno de los aspectos que, desde sus primeras representaciones, se asentó con mayor fuerza en el imaginario europeo. En El Dorado la representación del indígena se ajusta al arquetipo y, así, los americanos reflejados en el filme se caracterizan por su semidesnudez, los penachos de plumas, la pintura de rostro y cuerpo, adornos, lanzas, arcos y flechas. Más cuidadoso en este sentido se muestra el alemán Herzog, en cuyo largometraje se observa claramente la diferenciación que establece entre los habitantes del altiplano peruano (ataviados con amplios ponchos y sombreros adornados con madroños) y los de la zona amazónica, estos últimos sí afines a las características ya señaladas.

\subsection{5.- OTROS TÓPICOS.}

No podía descuidarse la atención a la ambientación musical en una película dirigida por alguien con fama de melómano como es Carlos Saura. Así, en El Dorado se aprecia la alternancia entre piezas musicales del Renacimiento español -algunas de ellas interpretadas por el cantautor Amancio Prada- y la música amerindia creada mediante quenas y ocarinas. $Y$ es que la música andina forma parte de ese conjunto de manifestaciones musicales (la ranchera mexicana, los ritmos caribeños, el tango argentino...) que se han consagrado como iconos auditivos de América en detrimento de aquellas otras características de las demás regiones de este vasto continente.

El contraste Europa/América se percibe también en lo referente a las armas, pues en el contexto "bélico" que recrea el filme es posible apreciar la oposición entre arcabuces y ballestas occidentales y los dardos envenenados utilizados por las tribus de la selva amazónica. En este sentido, mención obligada merecen las diversas embarcaciones que se observan a lo largo de toda la película (bergantín, barcazas y balsas); elemento indispensable primero para el descubrimiento y después para la conquista, las embarcaciones cuentan con una sólida tradición en la iconografía del Nuevo Mundo desde que una de las ilustraciones que acompañaban a la edición romana de las Cartas de Colón de 1493 presentara al rey Fernando el Católico indicando a las naves el rumbo que habían de seguir.

Por último, resta dejar constancia de la presencia recurrente que tiene la hamaca como lugar de descanso en varias secuencias de El Dorado. Al igual que sucede en el caso de las embarcaciones inmediatamente comentado, esta "cama"

tupinambas del Brasil observadas por Staden mientras fue su prisionero así como las experiencias de J. de Léry en su navegación por tierras cariocas. Vid. DE BRY, T.: Op. Cit., págs. 112-149. 
típica de latitudes americanas también se convirtió en referencia visual e iconográfica desde que André Thevet la tratara en su libro de viajes (1557) y Théodore Galle realizara un grabado en el que una América alegorizada aparecía despertándose de su descanso en una hamaca ante la presencia del navegante Américo Vespucio (1600).

Así las cosas, la Naturaleza exótica -atractiva y temible al mismo tiempo-, la antropofagia, la indumentaria indígena, la música andina, las embarcaciones, la utilización de las hamacas..., son elementos de los que se sirven los fotogramas de El Dorado para transmitir al espectador una iconografía estereotipada de América.

\section{3.- ICONOS Y MITOS DE LA EUROPA MODERNA Y CONTEMPORÁNEA.}

Aparte de los mitos y tópicos reseñados en los epígrafes previos, resulta muy interesante observar cómo en El Dorado quedan registrados también otra serie de iconos gestados en el ámbito europeo, los cuales se enumeran a continuación.

\subsection{1.- LA MUERTE DEL TIRANO.}

La incompetencia del gobernador Ursúa al mando de la expedición provoca una sublevación contra él por parte de sus capitanes más destacados. Éstos, con el pretexto de desearle un feliz año nuevo, penetran en el interior de su tienda. Pero los parabienes se transforman en un sangriento espectáculo: La Bandera, Montoya, Zalduendo, Aguirre y Guzmán clavan sucesivamente sus espadas y puñales en el cuerpo de Ursúa.

Estos fotogramas tienen un claro referente iconográfico para el espectador europeo: se trata de la muerte de Julio César en el senado romano el día de los idus de marzo del año 44, víctima de una conjuración en la que se le asestaron más de veinte puñaladas. Este icono pasó a formar parte del corpus cultural europeo, antes que por las fuentes latinas, a partir de la puesta en escena de la tragedia Julio César (1599) de Shakespeare.

De tal manera, con esta secuencia en la que se equipara la muerte del tirano romano con la del tirano Ursúa (en efecto, ésta es anunciada con el grito de " $i E l$ tirano ha muerto! ¡Viva el rey!'), Saura está trasladando una imagen de fuerte arraigo en el imaginario europeo a tierras americanas.

\subsection{2.- LA IMAGEN REGIA.}

Los créditos iniciales del filme aparecen en sobreimpresión sobre el retrato de Felipe II pintado por Antonio Moro (1557, Monasterio de El Escorial). No aparece 
el lienzo íntegro, sino que los fotogramas seleccionan los fragmentos más expresivos del mismo: se empieza por el rostro del rey y se continúa con la armadura, el "Toisón de oro" -uno de los distintivos de la Casa de Austria-, la empuñadura de la espada, las calzas, etcétera, para regresar finalmente de nuevo a la cara del monarca. Esta circunstancia puede explicarse a partir de la referencia constante que Felipe II constituye en las acciones de los expedicionarios dentro del filme.

En el transcurso de la película resulta muy llamativo el hecho de que en la ceremonia en la cual Guzmán es nombrado nuevo gobernador y "Príncipe de El Dorado, Perú y Chile" éste adopte exactamente la misma postura y porte elementos idénticos a los del monarca Habsburgo en el cuadro antes mencionado. Con este paralelismo deliberado, pues, el director de EI Dorado implanta otro icono occidental, el de ese poder regio europeo cercano ya al absolutismo que recrean los lienzos de la época, a tierras americanas.

\subsection{3.- LA "MUJER fatAL".}

En la expedición a El Dorado el gobernador Pedro de Ursúa cuenta con la compañía de la mestiza Inés de Atienza, su amante.

Carlos Saura, que se confiesa fascinado por la historia de amor que tiene lugar entre Ursúa y la mestiza, se muestra muy benevolente con el personaje de Inés de Atienza, cuyo comportamiento justifica como "un proceso de venganza y autodestrucción" por el cruel e injusto homicidio de su amado ${ }^{35}$.

Ahora bien, que ésta fuera la intención del director oscense con respecto del personaje interpretado por la actriz Gabriela Roel no impide que el filme permita al espectador llevar a cabo una lectura diferente, hasta opuesta si se quiere, del papel de doña Inés. $Y$ es que este personaje puede ser interpretado en clave de "mujer fatal".

La "mujer fatal" o femme fatale es un mito ${ }^{36}$ que surge en Francia durante la segunda mitad del siglo XIX y se extiende posteriormente por toda Europa. Grosso modo, puede definirse como una mujer cuyo gran poder de fascinación provoca la destrucción o la muerte de uno o varios hombres; aunque hay excepciones, ella

35 Cf. SAURA, C.: Op. Cit., págs. 188-189.

36 La de la "mujer fatal" es una categoría que se debate entre la pertinencia a los conceptos de mito, tópico, arquetipo, estereotipo, cliché, etcétera. En su consideración como "mito", la femme fatale constituye uno de esos personajes emblemáticos que, junto a otros como "Don Juan" o "Fausto", se han introducido en el imaginario colectivo occidental en los últimos doscientos años. Estos "personajes de ficción" guardan una doble relación con el concepto de "mito clásico": en primer lugar, no pueden existir sin el soporte de una narración ("relato"), sea ésta literaria o audiovisual; en segundo lugar, si los mitos grecolatinos conformaban una especie de red neuronal, los mitos contemporáneos establecen redes intertextuales en el imaginario. Un sucinta pero esclarecedora reflexión sobre estos aspectos es la que desarrolla GUBERN, R. en su ensayo Máscaras de la ficción. Barcelona, Anagrama, 2002, págs. 7-11. 
misma suele tener también un final desgraciado37.

Inés de Atienza se ajusta perfectamente a esta descripción: joven y hermosa, sabe que los integrantes de la expedición están pendientes de ella y la desean. El acaparamiento al que tiene sometido a Ursúa provoca la insurrección contra éste; tras la muerte del gobernador, otros dos capitanes (Juan de La Bandera y Zalduendo) se rinden ante sus encantos, resultando también víctimas de la trama urdida por Inés para preservar su seguridad dentro de un colectivo de hombres blancos. El propio Aguirre está a punto de sucumbir ante ella, pero se percata de su juego y así, para evitar ser víctima se convierte en verdugo y ordena la ejecución de la mestiza 38 .

Pero esta interpretación de Inés de Atienza como femme fatale tiene implicaciones más profundas dentro de la propia película de Saura. Efectivamente, la búsqueda de El Dorado y los relatos del guía Alonso de Esteban dan lugar a una mitología explícita, como ya se ha descrito y analizado en páginas anteriores. Sin embargo, esta particular configuración de Inés de Atienza como "mujer fatal" permite descubrir la mitología implícita presente en el filme. Así pues, la expedición comandada por Ursúa para la conquista de El Dorado aparece, mutatis mutandis, como un trasunto de la mítica de Jasón y los Argonautas en busca del vellocino de oro39 y, al igual que el héroe tesalio en su navegación hacia la Cólquide 40 o que el propio Ulises en el regreso a Ítaca 41 , los "marañones" deberán enfrentarse a sus particulares ama-

37 La bibliografía generada en torno a este tema es muy extensa; de especial interés resultan, no obstante, títulos como los siguientes: ALLEN, V. M.: The femme fatale. A study of the early development of the concept in midnineteenth Century Poetry and Painting (tesis inédita). Universidad de Boston, 1979; BORNAY, E.: Las hijas de Lilith. Madrid, Cátedra, 1990; DIJKSTRA, B.: Ídolos de la perversidad. La imagen de la mujer en la cultura de fin de siglo. Madrid, Debate, 1994.

38 Doña Inés es un personaje de escasa relevancia en las crónicas. Tan sólo se apunta que Ursúa, enfermo y aturdido por las fiebres que lo atormentaban, descuidaba sus obligaciones por ella. La Inés que Werner mo y aturdido por las flebres que lo atormentaban, descuidaba sus obligaciones por ella. La Inés que Werner Herzog crea en Aguirre, la colera de Diss es un personaje austero que nada tiene que ver con la dibujada por Saura. asi, no se la presenta como una mujer de belleza deslumbrante ni acaparadora de su amante; además, una vez muerto éste, ella se interna en la selva y desaparece.

39 El mismo hecho de que tanto Felipe II en el lienzo de Antonio Moro como el personaje de Fernando de Guzmán aparezcan portando el denominado "Toisón de Oro" -collar adornado con un carnero de oro, en alusión al mito clásico- parece venir a confirmar esta idea. Asimismo, otro paralelismo que puede establecerse entre ambas expediciones es la progresiva merma de tripulación que se produce en ellas, de héroes en la comandada por Jasón y de capitanes en la dirigida por Aguirre.

40 Aunque no existe una vinculación directa entre los Argonautas y las amazonas (aparte de uno de los doce trabajos de Hércules -que fue uno de los tripulantes del navío "Argo"-, consistente en sustraer el cinturón de Hipólita, reina de este pueblo de mujeres guerreras), no debe obviarse la escala que los compañeros de Jasón realizan en la isla de Lemnos, habitada únicamente por mujeres. Éstas, a quien Afrodita había castigado impregnándolas de un insoportable hedor, habían sido abandonadas por sus maridos y, para vengarse, habían exterminado a todos los varones de la isla. Las lemnianas, pues, presentan un comportamiento similar al de las amazonas en tanto en cuanto son también mujeres de carácter violento que viven sin hombres. En lo que respecta a las sirenas, Jasón y sus compañeros pasaron muy cerca de la isla donde ést bres. En lo que respecta a las sironas, Jason y sus compañ habitaban. Orfeo, que habia tomado parte en la expedición de los Argonautas marcando la cadencia de los remeros y calmando las olas impetuosas con su prodigiosa voz, anulo el embrujo de las voces de estas traicioneras criaturas con la belleza de su canto. Cf. GRIMAL, P.: Op. Cit., págs. 48a, 245a y 483b-484b.

41 Son tres las entidades míticas que dificultan el viaje de retorno de Ulises a su patria: así, a la seducción mortal de las sirenas se suman los retrasos en la navegación provocados por la hechicera Circe y la ninfa 
zonas y sirenas, si bien éstas nada tienen que ver con las descritas por el guía de la expedición. Debe tenerse en cuenta a este respecto que tanto la figura de la amazona como la de la sirena 42 están fuertemente vinculadas a la iconografía de la "mujer fatal". En función de ello -y salvando también las distancias-, Inés de Atienza se convierte, cual amazona, en una devoradora de hombres implacable y sin corazón y, cual sirena, en una mujer peligrosamente atractiva y seductora cuyos encantos conducen al hombre a la desgracia. Y, de hecho, en El Dorado la mestiza y Aguirre pueden equipararse en cuanto a su poder de destrucción -incluso, se complementanhasta el punto de que la sanguinaria personalidad del vasco queda empañada por la frívola actitud de doña Inés.

Así las cosas, esta mitología implícita que puede descubrirse en el filme hace que las palabras de Alonso de Esteban no queden reducidas a mera anécdota. Es más, supone que dichas palabras cumplan un doble objetivo: en primer lugar, reflejar el acervo mítico que los europeos del siglo XVI trasladaron a América, como ya se ha apuntado reiteradamente; en segundo, ponen de manifiesto cómo el arte cinematográfico permite el traspaso de mitos europeos de la Edad Contemporánea como es el de la femme fatale a la América de la Conquista. De tal forma, en la imagen de América reflejada en El Dorado el europeo actual, en este caso Carlos Saura, provoca la confluencia de dos imaginarios occidentales: el mítico clásico y el mítico contemporáneo.

$Y$ es que en el filme del director aragonés el estereotipo de la femme fatale (denominémoslo así, puesto que es una categoría que oscila entre "mito" y "tópico", como la propia imagen de América) actúa como un magnífico nexo entre ambos corpora.

El gráfico que se incluye pretende ilustrar el efecto de retroalimentación que se produce entre algunos de los mitos presentes en El Dorado.

\section{4.- CONCLUSIÓN.}

Más que descubrir América, podría decirse que los hombres que participaron en su conquista consiguieron "inventarla" poco a poco al proyectar sobre ella una

Calipso, respectivamente, personajes ambos que la tradición cultural ha consagrado como "mujeres fatales". 42 Cf. BORNAY, E.: Op. Cit., págs. 275-282. En este sentido, los pintores adscritos al Prerrafaelismo, al Simbolismo y al Modernismo, de cuyos pinceles surgieron las primeras imágenes de la femme fatale, trataron con frecuencia el tema de la sirena. Por ejemplo, Edward Burne-Jones pinta en 1885 En las profundidades del mar (The depths of the sea). El también inglés John William Waterhouse dedica varios lienzos a este personaje mitológico: Ulises y las sirenas (Ulysses and the Sirens, 1891), La Sirena (Estudio) [The Mermaid (Study), 1892], La Sirena (The Siren, 1900) y Una Sirena (A Mermaid, 1901). Asimismo, Herber Draper desarrolla su Ulises y las Sirenas en la última década del siglo XIX, es decir, en pleno auge finisecular del mito de la "mujer fatal". De otro lado, en el filme El ángel azul (Der Blaue Engel, 1930) la aparición de un mascarón de proa con forma de sirena en el local donde se desarrolla la acción fílmica tiene un carácter programático, pues anticipa el malévolo influjo que Lola-Lola está a punto de ejercer sobre el Profesor Rath. 
serie de categorías preexistentes en el imaginario colectivo occidental y destinadas a obtener la tan ansiada alteridad con respecto de la realidad europea.

El conjunto de leyendas, símbolos, arquetipos, etcétera, exportados a tierras americanas no sólo se vio reflejado en las fuentes literarias sino que alcanzó también a las artes plásticas y decorativas, dando lugar con ello a la aparición de una iconografía sumamente peculiar que quedó definida por constantes figurativas y por estar a caballo entre el mito y el tópico.

En el siglo XX la imagen de América se hace extensible a un nuevo soporte, el arte cinematográfico. La película El Dorado, a cuyo análisis se han dedicado las páginas precedentes, constituye una excelente demostración de cómo el llamado "Séptimo Arte" se hace eco de la iconografía americana y, más aún, de cómo sus mecanismos poseen la capacidad de enriquecerla.

Tal y como se ha venido argumentando en epígrafes anteriores, Carlos Saura recrea en su largometraje una serie de mitos y tópicos asociados tradicionalmente al continente americano. En lo que al aspecto mítico se refiere, las alusiones a $\mathrm{El}$ Dorado -con unos inolvidables fotogramas iniciales que suponen la adaptación cinematográfica de la iconografía acuñada por De Bry en su famoso grabado-, a las amazonas, a las sirenas y a los acéfalos ejemplifican no sólo ese corpus mitológico surgido de la confluencia entre las fuentes clásicas y medievales europeas y las creencias prehispánicas de América, sino también el recurso a la fantasía y la invención del que hicieron gala conquistadores y cronistas para intentar comprender una realidad, la americana, que se presentaba misteriosa y enigmática para ellos. Asimismo, la ambientación del filme se sirve de numerosos tópicos vinculados al Nuevo Mundo, entre ellos la vegetación exuberante, una fauna exótica, la antropofagia, las masacres de indios, la indumentaria indígena, la música andina, los dardos envenenados, las embarcaciones y las hamacas.

Sin embargo, el director oscense no se limita a llevar a cabo en su película un mero compendio de iconos fijados con anterioridad. Por el contrario, en El Dorado la imagen de América ha sido enriquecida añadiendo a los mitos clásicos y a la tradición medieval allí trasladados por el hombre del Renacimiento otros iconos gestados en el ámbito europeo durante la Edad Moderna (caso del asesinato colectivo del tirano fijado iconográficamente a partir del texto de Shakespeare y el canon estético establecido en los retratos regios y cortesanos del siglo XVI) así como mitos surgidos en la Edad Contemporánea (como es el de la "mujer fatal") que el lenguaje y los recursos cinematográficos permiten al hombre del siglo $X X$-en este caso Saura- proyectar sobre el continente americano.

En este orden de cosas, la identificación del personaje de Inés de Atienza con el mito de la femme fatale -sea o no intencionada por parte de Saura- supone una lectura de tipo cultural muy sugerente para el espectador, dado que llena de sentido 
la que en un primer momento parecía una alusión aislada y trivial a los mitos grecolatinos por parte de Alonso de Esteban, al tiempo que multiplica la coherencia interna del filme si consideramos el siguiente planteamiento esquemático:

$Y$ es que, atendiendo al esquema anterior, Saura actúa como un nuevo De Bry (o un nuevo Thevet, Staden, Eckhout, etcétera); es decir, el artista europeo -sea grabador o cineasta, pertenezca al siglo XVI o al XX-proyecta sobre las latitudes americanas imaginarios míticos gestados en Occidente: los renacentistas, el que bebe de la Antigüedad Clásica, época que proponen como paradigma; los actuales, mitos surgidos en el ámbito europeo en épocas más recientes, como es el de la "mujer fatal", que ha cosechado enorme fortuna en el ámbito cinematográfico43.

Se trata, en definitiva, de interpretar la película El Dorado en clave de confluencia de mitos (antiguos y contemporáneos) en una geografía ajena a la elaboración de los mismos y a partir de un soporte novedoso en la iconografía de América como es el Cine.

43 La nómina de películas que recrean el mito de la femme fatale es extraordinariamente extensa. Citamos a continuación un elenco que se propone ilustrar la variedad de épocas, directores y movimientos cinematográficos que se han inspirado en este tema: Lulú (Die Buchse der Pandora, 1928), de Georg Wilhelm Pabst; El Ángel azul (Der Blaue Engel, 1930), de Joseph von Sternberg; La Golfa (La Chienne, 1931), de Jean Renoir; El halcón maltés (The maltese falcon, 1941), de John Houston; La mujer pantera (Cat people, 1942), de Jacques Tourneur; Perdición (Double Indemnity, 1944), de Billy Wilder; La mujer del cuadro (The woman de Jacques Tou 1944), Perdicin (Double Indemnity, 1944), de Blly Wilder, La mujer del cuadro (The woman in the window, 1944) y Perversidad (Scarlet Street, 1945), ambas de Fritz Lang; La dama de Shangai (The lady from Shangai, 1948), de Orson Welles; Niágara (Niagara, 1953), de Henry Hathaway; Ese oscuro objeto del deseo (Cet obscur object du désir, 1977), de Luis Buñuel; Salomé (2002), del propio Carlos Saura, y un largo etcétera. En este respecto, una magnífica disertación sobre la "mujer fatal" plasmada en la pantalla es la que lleva a cabo GUBERN, R.: Op. Cit., págs. 58-96. 